\title{
A ACULTURAÇÃO DA TRIBO TUPARÍ *
}

\author{
Franz Caspar
}

\section{Introdução}

Os estudos sôbre o contacto de culturas diversas ocupam posição de relêvo na antropologia cultural, cabendo o primeiro lugar aos que focalizam as influências da civilização euro-americana sôbre as populações tribais. Êste destaque não se justifica apenas pela utilidade prática dessas pesquisas para a assistência aos aborígenes e a política colonial, como também pelo ensejo oferecido pelos processos aculturativos de se observarem numa área limitada e em sua fase dinâmica fenômenos de grande importância, tais como a difusão, a fusão e o desaparecimento de culturas e de elementos culturais.

Ademais, êsses processos nos ajudam a compreender uns tantos aspectos das próprias culturas em aprêço. Não é por acaso que um povo ou uma tribo recebe determinados elementos culturais e rejeita outros Necessidades latentes, de ordem material e social, se tornam manifestas ao contacto com culturas estranhas e, assim, suscetíveis de observação. A seleção a que a cultura "receptora" procede na aceitação de elemer. tos da cultura "doadora" e o grau de persistência com que uma cultura "passiva" se aferra a determinados complexos lançam às vêzes a luz decisiva sôbre a escala de valores que rege a vida de uma determinada scriedade.

Por fim, cabe aos estudos sôbre aculturação o mérito de despertarem o interêsse por um problema desprezado pela investigação histórico-cultural e que se pode resumir na pergunta: Quais são, em suma, as coisas que a nossa civilização oferece em sua periferia aos portadores de culturas estranhas, p. ex., primitivas? Não são, por certo, as que representam para nós em essência a nossa civilização. Nem tampouco a respectiva cultura continental em sua totalidade. Quais, então?

Neste artigo pretendo resumir as observações feitas em duas viagens de estudo aos índios Tuparí do Brasil ocidental. Em 1948 convivi cêrca de meio ano com essa tribo, tornando a visitá-la em 1955. Por motivos circunstanciais, porém, a segunda visita se reduziu a um período de três meses $^{1}$.

* Tradução de Egon Schaden. O texto original, em alemão, é publicado na "Kölner Zeitschrift für Soziologie und Sozialpsychologie", vol. 9, n.o 2, Köln-Opladen, 1957. 


\section{Habitat e cultura da tribo}

Os Tuparí vivem na região das nascentes do Rio Branco (em mapas antigos "Rio São Simão"), tributário da margem direita do Guaporé, no território marginal norte-ocidental do planalto mato-grossense, pertencente à bacia amazônica. O seu habitat é a floresta tropical; o relêvo do solo se caracteriza por uma formação suavemente ondulada. Os riachos que banham o seu território, bem como o curso superior do próprio Rio Branco, não são navegáveis. $\mathrm{O}$ ano se divide em dois períodos: a estação chuvosa, de mais ou menos novembro até abril, e a estiagem, de maio a outubro. A êsse ciclo se adaptam, em grande parte, a economia e as demais atividades dos Tuparí.

A cultura dos Tuparí corresponde, mesmo em muitos pormenores, à de várias outras tribos das imediações. Também a língua tem muita semelhança com a de umas tantas tribos vizinhas, embora os vizinhos mais próximos, os Arikapú e os Jabutí, falem idiomas inteiramente diferentes. As relações com tôdas essas tribos é facilitada pela circunstância de que a língua dos Makuráp, outrora influentes e poderosos, se tornou o idioma intertribal no território do Rio Branco e no do Rio Colorado.

À semelhança do que se observa, de modo geral, nas populaçõe. aborígenes das regiões tropicais sul-americanas, os Tuparí ignoram a escrita, qualquer sistema desenvolvido de numeração e cálculo, bem como técnicas de trabalhar metais. Não se enquadram tampouco em nenhıma entidade política ou sistema comercial de âmbito mais largo, viven. do, por conseguinte, em relativo isolamento.

Moram em grandes casas comunais, redondas e em forma de cúpula, cobertas de fôlhas de palmeira que descem até o chão. No ano de 1955 restava uma única habitação dêsse tipo; em época anterior teria havido, segundo um relato, 16 dessas casas comunais, segundo outro, até 30 espalhadas por todo o território ocupado pela tribo. Em cada uma dessas construções morava um grupo de 30 ou mais famílias. Estas não formavam uma família-grande, tendo apenas em parte laços de parentesco estreitos com o cacique. Os vários grupos eram independentes uns dos outros, não estando sujeitos a nenhum cacique tribal su.perior. Jogos de bola de cabeça, festas de bebida, cerimônias pubertárias solenes, casamentos exógamos e empreendimentos comuns contra tribos hostis ofereciam oportunidade para cultivar as relações entre os diferentes grupos.

No interior de cada grupo ou comunidade de habitação as várias famílias são essencialmente autonômas. O poder do cacique ou chere de grupo é muito limitado. A função mais importante do grupo é, além da construção e ocupação conjunta da mesma casa comunitária, o trábalho cooperativo da roçada e cultivo das roças, que se repete de ano 
em ano. Todos os homens e mulheres cooperam nas plantações do cacique, sendo êste obrigado, por sua vez, a prestar, em certa medida, o seu auxílio pessoal na roça de cada um de seus companheiros de grupo. No final das contas, o cacique indubitàvelmente trabalha mais do que qualquer cutro companheiro de grupo, mas em compensação tem roças maiores e, por conseguinte, maior abundância de alimentos. Daí the advém especial prestígio, sobretudo porque pode convidar muitas vêzes não só os membros do próprio grupo, como os vizinhos, para grandes festas de bebida. Essa dependência entre o trabalho pessoal e o prestígio faz com que a dignidade de chefe seja apenas condicionalmente heredi. tária: um filho de cacique deve revelar, ao lado de outras qualidades de chefe, pronunciada capacidade e dedicação no cultivo da terra.

Não há dúvida, poils, de que é grande a importância dos liames comunitários. Mas o trabalho cooperativo só periòdicamente une os membros do grupo, em particular por ocasião da roçada. Assim, a família biológica permanece a unidade social mais importante, na economia como no convívio cotidiano.

O matrimônio é, em geral, monógamo; apenas homens muito trabalhadores, especialmente caciques, podem ter duas ou mais mulheres. A iniciativa da escôlha do cônjuge parte em geral do homem, sem que êste consulte a mulher. Êsse costume, que provàvelmente existiu também nas tribos vizinhas, talvez explique a extraordinária passividade com que aí as índias, desde o início do contacto, se deixavam entregar aos seringueiros, e, por êstes, a outros donos.

No tocante à descendência, os Tuparí consideram tanto a linha paterna como a materna, acentuando, porém, mais a primeira.

Além da divisão sexual de trabalho, não há estruturação social se... gundo ocupações, nem tampouco estratificação em classes. Abstração feita da mencionada cooperação nos afazeres da roça, cada família é econômicamente autárquica, sendo equitativa a distribuição de tarefás entre o homem e a mulher. Certo, a mulher é nitidamente subordinada ao homem, mas ela não tem, em absoluto, condição de escrava. Ao lado da lavoura, os Tuparí praticam a caça com arco e flecha, a pesca com auxílio de plantas tóxicas, a coleta de frutos silvestres e a captura de pequenos animais. Os seus animais domésticos são, além de cães de caça, algumas poucas galinhas e patos. A tecelagem, o trançado, a cerâmica e outras técnicas artesanais são bastante desenvolvidas. Por outro íado, falta qualquer atividade artística com representações figuradas ou ornamentação menos rudimentar.

As idéias relativas ao Além são bastante ricas. Em suas sessões mágicas os xâmanes entram, narcotizados, em comunicação com as almas dos mortos e de numerosos "xamãs dos tempos primevos", que habitam no "céu" e em parte também na terra. Cabe-lhes também manter 
afastados da maloca os maus espíritos (tárüpa). Ritos complicados acom. panham o ciclo de vida: na fase de lactente, na puberdade, após o parto e depois da morte.

$\mathrm{Na}$ época de seu primeiro contacto com a civilização os Tupari não constituíam uma tribo numerosa, nem mesmo segundo os conceitos sulamericanos. Não é, entretanto, exagerada a estimativa de umas 3000 almas. A tribo não possuía então inimigos com que estivesse em pé de guerra e mantinha relações de amizade com várias tribos. Todavia, os Tuparí, segundo muitos relatos dêles próprios e de outrem, eram tem:dos em tôda a área como guerreiros e antropófagos.

Não é fácil, naturalmente, fazer uma idéia da "atmosfera". outrora reinante nas malocas da tribo. Há numerosos indícios de que não faltavam tensões, hostilidades, receios e outros fenômenos negativos da vida individual e social. Não obstante, a predominância, entre os Tuparí 'śbreviventes, de uns tantos traços positivos de personalidade, como atitudes seguras e tranqüilas, reduzida agressividade, espírito comunicativo, franca disposição para brincadeiras inocentes, grande amor às crianças etc., parecem indicar que na tribo o primitivo ambiente social deve ter sido melhor do que a sua fama.

\section{História do contacto}

Tal como acontece em extensas áreas da Amazônia, também aqui os seringueiros foram os primeiros representantes da civilização ocidenta1. Do Guaporé, ainda pouco navegado por volta de 1900, foram subindo, entre 1910 e 1920, os afluentes Colorado e Branco, ao longo de cuja parte navegável fundaram os seus estabelecimentos. Índios $\mathrm{Ma}$ kuráp, Wayoró, Aruá e Jabutí se integraram no sistema de trabalho ligado à exploração da borracha. Parte dêles passou a morar inteiramen. te com os estranhos, trabalhando o ano todo no "barracão" (centro de coleta da borracha). A êsses passaremos a chamar, simplesmente, de "índios do barracão". A maioria dos índios, porém, constinuou por certo tempo a morar na primitiva maloca (pelo que os denominamos "índios de maloca"), sendo aproveitados só periòdicamente para o trabalho, em especial para tarefas auxiliares, como roçadas, construção de casas etc.

As enfermidades dos brancos não tardaram a dizimar de tal modo êsses aborígenes que daí a poucos anos os emissários dos seringalistas avançaram até o território dos Arikapú e mesmo até o dos Tuparí, que moravam a vários dias de viagem para o interior. Foi em 1927 que um empregado, acompanhado de alguns índios mansos, entrou pela primei. ra vez nas malocas dos Tuparí, levando consigo um grupo de homens a fim de trabalharem em Paulo Saldanha, na época lugar relativamente movimentado como centro de coleta de borracha silvestre.

Havia anos que os Tuparí tinham visto seus vizinhos de posse de utensílios de ferro, cujas vantagens decisivas logo compreenderam. Não 
hesitaram então em aproveitar a oportunidade para, por sua vez, obte rem machados e facas. Mas imediatamente doenças outrora desconhe. cidas, que já tinham vitimado a maioria dos vizinhos, passaram a manifestar-se entre êles de maneira desastrosa. Tratava-se principalment: do defluxo ou catarro, infecção contra cujo virus os índios não têm imunidade e que, transformando-se no decurso da moléstia provàvelmente em infecção mista (pneumonia, bronquite aguda etc.), em muitíssimcs casos produzia a morte. Já em 1934, poucos anos, portanto, após o primeiro contacto dos Tuparí com a civilização, o etnólogo alemão Dr. E. H. Snethlage encontrou sòmente três casas, com cêrca de 250 habitantes ${ }^{2}$.

Antes de prosseguir em sua viagem de coleta etnográfica, Snethlaga permaneceu entre os Tuparí apenas uma semana, aproximadamente, 1evando depois consigo, como carregadores, um grupo dêsses índios a São Luís, um barracão que havia sido fundado mais a jusante. A partir de 1934 os Tuparí parecem ter visitado São Luís quase anualmente em grupos mais ou menos numerosos. Em geral ia buscá-los, na estiagem, algum seringueiro em companhia de índios civilizados, a fim de fazerem novcs roçados. Sob a fiscalização de um empregado trabalhavam entãu algumas semanas e às vêzes até vários meses. A renumeração consistia, na maioria dos casos, em um machado ou faca, fósforos, sabão e saí; mais raramente recebiam alguma roupa de algodão, pratos, canecos, colheres, espelhos, pentes e outros utensílios usados também pelos serin gueiros .

Os Tuparí eram trabalhadores cobiçados, principalmente porque a mão de obra se tornava escassa em conseqüência da elevada mortalidade entre os índios de barracão. Todavia, em geral não ficavam contentes com a remuneração de seu trabalho, nem com as condições de alimentação e morada no barracão, infferiores ao padrão a que estavam acostumados. Assim mesmo, nos anos que se seguiram a 1940, alguns rapazes passaram a morar definitivamente em São Luís, provàvelmente por in. sistência da administração do barracão.

A Segunda Guerra Mundial veio imprimir novo rumo à vida dos índios do Rio Branco. A borracha subiu de preço e o dono de São Luís contratou um número relativamente considerável de seringueiros estranhos, em grande parte gente do chamado "exército da borracha". Èste era um ajuntamento de elementos socialmente indesejáveis, recrutados à fôrça, durante a guerra, em tôdas as partes do Brasil e transportados, sob guarda militar, à região do Amazonas, a fim de trabalharem nos seringais. E' verdade que no Rio Branco êsses trabalhadores provàvelmente nunca chegaram a ultrapassar o número de 100 , mas como assim mesmo superavam o das famílias dos índios de barracão, de São Luís, 
não deixaram de causar grave perturbação na pequena comunidade brasileiro-indígena em formação .

Para os índios a conseqüência mais incisiva dêsse convívio foi a promiscuidade quase geral das mulheres indígenas com os estranhos. Em parte os seringueiros tomavam as índias de barracão como concubinas, ao passo que a maior parte preferia as relações ocasionais com as mulheres dos índios. A freqüência dessas relações e a facilidade com que as índias se entregavam, dentro em pouco se tornou conhecida em todo o território do Guaporé. Em paga as índias recebiam sabonetes, perfumes, tecidos e coisas semelhantes. Vários seringueiros iam até as malocas dos Jabutí, distantes dois ou três dias de caminhada, negociavam mulheres jovens a trôco de utensílios ou espingardas, conservavamnas por algum tempo como concubinas e depois passavam-nas adiante. Houve também casos de rapto e violentação de índias. Nessa época, um único índio de barracão reagiu à fôrça contra tal situação, matando com três flechadas o sedutor de sua espôsa.

Para os Tuparí, essa penetração de novos seringueiros não teve a princípio significação imediata, embora não deixasse de reduzir a fôrça de atração exercida pelo barracão. Evitavam sobretudo que as mulheres os acompanhassem em suas visitas.

Era essa a situação quando em 1948 o jornalista jugoslavo T. Sekelj chegou a São Luís com sua espôsa e mais dois companheiros, visitando também os Tuparí. Passou três semanas na tribo. Os homens que na marcha de regresso the serviram de carregadores conduziram-no então para a sua maloca.

A partir de 1948 os Tuparí iam mais amiúde a São Luís, indubitàvelmente em conseqüência dos esforços de um novo administrador. Daí por diante, a maioria dos homens passava cada ano vários meses no barracão, muitos dêles em companhia da mulher e dos filhos. Em 1952 o bispo católico de Guajará-Mirim, Monsenhor F. X. Rey, fundou uma missão em São Luís. Parecia iniciar-se um novo desenvolvimento. A atividade médica do missionário, coroada de êxito, o grande número de presentes e, de modo notável, o melhor tratamento dispensado aos índios pela emprêsa exploradora do seringal, em conseqüência da pressão moral exercida pela missão, aumentaram a fôrça de atração que São Luís exercia sôbre os Tuparí.

Em fins de 1953 dois emissários do barracão induziram a maioria dos Tuparí, bem como os índios ainda independentes das demais tribos, a abandonarem as suas malocas, a fim de se estabelecerem definitivamente em São Luís. Êsses emissários ameaçaram os índios de, caso não tomassem tal decisão, serem procurados e mortos a tiros por soldados que, segundo afirmavam, já se encontravam a caminho da região. Na estação chuvosa de 1953-54 os Tuparí trabalharam nas roças de São 
Luís e colheram castanhas silvestres. Não tardou que o defluxo e outras moléstias viessem causar novas vítimas. Mas a catástrofe decisiva haveria de sobrevir em junho de 1954. O filho de um seringueiro, vindo do Rio Guaporé, trouxe o sarampo, enfermidade até então desconhecida no Rio Branco e que, dentro de poucas semanas, matou mais da metade dos índios que viviam em São Luís e nas cercanias. Não houve grande diferença, quanto à mortalidade, entre os índios das malocas e os do barracão.

O resto dos Tuparí se refugiou na maloca da qual se tinham retirado havia meio ano. Mais ou menos meio ano após o infortúnio encontrei os sobreviventes numa habitação recém-construída, reduzidos a um total de 66 pessoas, ao passo que em 1948 eu conhecera 200, aproximadamente.

\section{O mundo dos brancos}

Quando se fala do contacto dos Tuparí com a civilização, cumpre não esquecer que os índios não travaram conhecimento com o que comumente se chama de "cultura ocidental" ou sua variante brasileira. O que, de fato, lhes foi apresentado não era nada mais do que pequenos recortes desconexos dessa sociedade mais ampla: uma reunião fortuita de brancos, mestiços e negros, poucos dos quais tinham mulher e filhos; administradores do seringal, substituídos cada dois ou três anos ou a menores intervalos ainda, variando desde o europeu culto até o mulato analfabeto; um seringalista, que poucas vêzes ia ver pessoalmente as suas concessões de terras; alguns polícias, dos quais o seringalista, graças à sua simultânea qualidade de funcionário municipal, se podia fazer acompanhar, vez por outra, em suas visitas a São Luís. Em conjunto, nenhuma amostra representativa da sociedade brasileira, mas um pombal de aventureiros e de empregados de funções em geral efêmeras, a que se acrescentava o contacto com um punhado de "doutores" europeus: etnólogos e jornalistas, e, finalmente, com alguns missionários.

Ao lado do ir e vir de patrões, empregados e seringueiros havia, contudo, um continuum fàcilmente perceptível aos índios: o "barracão". $\mathrm{Na}$ casa relativamente espaçosa, embora de construção primitiva, morava o administrador, o "cacique dos seringueiros". Ali os seringueiros, que trabalhavam de empreitada, recebiam mantimentos, munições e roupas; ali também entregavam a borracha. Era ali que chegava na estação das águas um pequeno rebocador ou uma lancha a motor com suas chatas, a fim de levar para Guajará-Mirim o produto de um ano de trabalho: de borracha, castanhas do Pará, ipecacuanha e às vêzes também o excesso da produção agrícola, como milho, feijão e outras coisas mais.

Dêsse continuum faziam parte igualmente os índios do barracão, provenientes de várias tribos, os quais viviam em São Luís e nos arredores como seringueiros e trabalhadores, tendo conservado ainda muita 
coisa de suas culturas tradicionais. Com êles os Tuparí se entendiam em makuráp, a "língua franca" da região. Não há dúvida de que para os Tuparí êsses índios de barracão representavam, de algum modo, um ideal acessível. Os Tuparí teriam gostado de usufruir as vantagens ligadas à vida no seringal - entre as quais a posse de indumentária, armas de fogo, açúcar, sabão e outras coisas - sem todavia aceitarem o que de negativo decorria do convívio constante com os brancos. Os índios do barracão, por seu turno, olhavam com desdém os seus vizinhos nus e ignorantes, o que naturalmente não passava desapercebido aos Tuparí. Mas, como participantes de dois mundos, os índios do barracão ofereciam aos Tuparí a vantagem de atenuar o choque que, de outra forma, êstes teriam sofrido em seus contactos com os seringueiros por ocasião de suas visitas a São Luís. Eram a prova de que afinal havia possibilidade de se vencer o abismo que separava êsses mundos.

Os índios do barracão, bem como as malocas próximas de São Luís, serviram também de para-choque nas duas ocasiões em que as exigências categóricas dos brancos colidiram violentamente com o mundo aborígene. A primeira interferência súbita nas condições de vida reinantes no Rio Branco deu-se pouco antes de 1934, quando um funcionário do Serviço de Proteção aos Índios retirou de São Luís e das aldeias mais acessíveis um número só aproximadamente conhecido de índios Makuráp, Aruá e Jabutí, levando-os, contra a vontade dêles, a uma colônia de trabalhadores das proximidades de Guajará-Mirim ${ }^{3}$. Êsse funcionário, posteriormente dono de São Luís, lamentou mais tarde a perda dêsses trabalhadores. Mas o simples fato de estar, sem dúvida, legitimado para a ação que empreendeu, conferiu-lhe especial autoridade aos olhos dos indígenas. A segunda violência, motivo de grande alvorôço em todo o Território, passou-se em São Luís no ano de 1937. O primeiro administrador contratado pelo proprietário procurou pôr em prática um novo sistema de trabalho com castigos corporais. Levou a coisa a tal ponto que alguns índios Makuráp trucidaram todos os estranhos que viviam em São Luís, inclusive o administrador, duas mulheres e uma criança de peito. Uma comissão policial enviada então ao Rio Branco não tomou medida punitiva de espécie alguma, em parte talvez pela certeza de que a reação dos silvícolas fôra o único meio de fazerem frente às injustiças de que eram vítimas.

Mas é certo que tais violências de um e outro lado constituíam casos excepcionais. Não se pode, sobretudo, negar que os seringueiros (abstração feita do abuso das mulheres) mantinham relações de camaradagem com os aborígenes. Ademais, o convívio com os seringueiros era facilitado pelo fato de que êstes em grande parte provinham da população rural de posição social inferior, produtos de cruzamento com sangue indígena, e êles próprios analfabetos. Assim, os seus modos de vida não 
ultrapassavam, em essência, a capacidade de representação dos índios e, no tocante às relações de dependência que os prendiam ao barracão, uns e outros se encontravam mais ou menos na mesma situação. Os seringueiros habitavam primitivos ranchos de fôlhas de palmeira, dormiam em rêdes, não possuíam mobilia alguma além de uma mala ou um caixote, cozinhavam os seus alimentos à maneira indígena numa fogueira aberta, vestiam simples calças e camisas de algodão, calçavam sapatos feitos por êles próprios, de látex defumado, com auxílio de fôrmas de madeira. Ao lado de alguns mantimentos importados do baixo Amazonas, usavam, em sua alimentação, principalmente os produtos das roças de São Luís e dos arredores - raízes de mandioca, farinha de mandioca, milho, arroz, feijão, bananas - a que acrescentavam os produtos da caça, peixes, tartarugas e frutos silvestres, colhidos por êles próprios. Muitos não rejeitavam sequer larvas de bezouros e outros insetos.

Os Tuparí tinham as suas idéias sôbre a proveniência e a natureza dos forasteiros. Baseando-se na classificação que costumavam fazer de seus vizinhos, em que o critério era o idioma, distinguiam duas "tribos" de seringueiros e empregados: a dos "brasileiros", que falava português, € a dos "bolivianos", que falava o espanhol. Em virtude de sua função diversa, que os índios conheciam menos através de observação direta do que pelas coisas que dêles ouviam dizer, os soldados e a polícia não se enquadravam bem em nenhuma dessas duas tribos, vindo a constituir, por isso, a tribo dos "soldados". Até 1948 certamente não chegara aos índios a notícia da existência de outros povos. Só com o aparecimento de aviões, que de tempos em tempos passaram a sobrevoar a região, voltaram a atenção para o fato de haver no Brasil centros de população mais distantes e maiores. Hoje os índios mais "civilizados" estão bastante familiarizados com nomes de cidades como Pôrto Velho, Cuiabá, Manaus, São Paulo e Rio (de Janeiro), embora não se saiba qual a representação que ligam a essas palavras.

Não era possível, em absoluto, que os Tuparí pudessem ter uma noção mais ou menos adequada das instituições sociais em vigor no mundo dos brancos. A única instituição, observável entre os seringueiros, que ultrapassava a família biológica, era o "barracão", o centro econômico da extração da borracha. Os índios comparavam a posição do administrador com a de seus próprios caciques, a dos seringueiros com a de um simples companheiro de tribo. O que não conseguiam compreender nessa administração era a divisão de trabalho, segundo a qual o "cacique dos seringueiros" ficava isento de trabalho físico. Entre êles a autoridade do cacique tinha por base a posse de extensas roças e de grandes provisões de mantimentos obtidos com trabalho pessoal. Os chefes dos forasteiros, por seu turno, se caracterizavam em primeiro lugar pela posse de artigos de tôda espécie, não sòmente de consumo, mas também de capital, e, em 
segundo, pela sua atitude em face do trabalho braçal: ordenavam os outros que o realizassem, sem êles próprios se disporem a ajudar.

Tampouco as representações religiosas dos adventícios podiam ser compreendidas de alguma forma pelos Tuparí ou mesmo pelos índios de barracão. Decisivo era a êste respeito o fato de que os seringueiros, embora batizados, pràticamente não tinham vida religiosa. E até 1952 eram raras as visitas de algum missionário católico ao Rio Branco. Assim, os índios continuaram, pràticamente sem perturbação, a observância de seus costumes mágico-religiosos. Parte dos seringueiros zomíava dêles; parte mantinha atitude neutra; mas havia também alguns que recorriam ao tratamento mágico dos médicos-feiticeiros. Por seu turno, porém, não ofereciam os silvícolas coisa alguma que pudesse ser por êles imitada e integrada no sistema de relações com o sobrenatural.

Menos difícil do que a compreensão das instituições sociais e das representações religiosas era, para os indígenas, a percepção de todo o equipamento material levado pelos ádvenas ao Rio Branco. Machados, facas, arame de ferro, agulhas, pratos esmaltados, tigelas, colheres e tesouras não tardaram em cair na posse dos ínđios, que também se acostumaram ao uso do sal, dos fósforos, do sabão. Também para os Tuparí havia possibilidade de partilharem dêsses tesouros, contanto que trabalhassem bastante tempo em São Luís. Peças de vestuário, mosquiteiros e rêdes de origem fabril começaram a entrar no barracão, chegando, vez por outra, até aos Tuparí. Além disso, viam-se, entre os forasteiros, serras, plainas e outras ferramentas, bem como o vaporzinho e a lancha a vapor. Com tôdas essas coisas os índios do barracão e também os Tuparí se familiarizaram sem dificuldade. Havia apenas um mistério: como é que os brancos produziam tôdas essas coisas? Essa questão, porém, parecia preocupar apenas os espíritos mais curiosos.

\section{A influência da civilização}

Era êsse o novo mundo com que os Tuparí se confrontaram. Antes de tentarmos acompanhar, passo a passo a evolução que daí por diante se processaria, cumpre perguntar por que o contacto se desenvolveu sempre de forma pacífica. Pois na região do Guaporé ainda hoje existem tribos empenhadas, em suas relações com os brancos, numa implacável guerra de escaramuças, sustentada, aliás, de um e outro lado. Decisivo foi, sem dúvida, o fato de os exploradores da borracha não se apoderarem das terras distantes em que moram os Tuparí, mas de os procurarem apenas como mão de obra para uma ajuda periódica. Estavam interessados em relações amistosas. O mesmo se pode dizer dos Tuparí. Desde tempos imemoriais, êstes haviam vivido em trato amigável com diferentes tribos vizinhas, e de suas narrações se depreende, de forma inequívoca, que, no correr dos tempos, receberam dos vizinhos grande número de elementos culturais: adornos, música, plantas úteis e, provàvelvente, também re- 
presentações e práticas religiosas. Parecem ter sido uma tribo relativamente primitiva, ávida de aprender coisas novas. Quando, de repente, observaram a existência de utensílios de ferro entre os vizinhos ocidentais, era, por isso, inevitável que êles próprios os desejassem também.

Economia. - A múltipla superioridade dos utensílios de ferro sôbre os antigos machados de pedra e as facas de pupunha era por demais evidente. Está aí a primeira e, ao mesmo tempo, a mais incisiva influência que veio determinar o desenvolvimento ulterior da tribo. A derrubada anual de grandes áreas de mata virgem, tal como se impunha pelo ambiente natural e pelas técnicas de lavoura, era de tal modo cansativa e morosa que os Tuparí procuraram entrar, a qualquer preço, na posse dos novos utensílios, mesmo sob o perigo de sucumbirem vitimados pelas moléstias dos brancos. Em outros tempos, referem êles próprios, era freqüente comerem madeira podre ou frutos pouco comestiveis, para "enganar" o estômago quando se haviam esgotado as provisões de milho e de mandioca. Afirmam sem rodeios que, em períodos de penúria, houve até casos isolados de antropofagia: homens Tuparí matavam pessoas da própria tribo ou de tribos estranhas, a fim de assá-los e comê-los.

A adoção de utensílios de ferro não tardou a melhorar, de forma decisiva, a situação alimentar. Daí em diante todo Tuparí estava em condições de abrir grandes roças em prazo relativamente curto. Durante o ano todo havia mantimentos saborosos e em quantidade suficiente. Mais ainda, as provisões eram tamanhas que em qualquer época se podia, quase sem limitação, realizar grandes festas com bebida de milho e de mandioca.

Seguiu-se daí mais outra transformação. Anteriormente os Tupari haviam dependido, em escala muito maior, dos resultados da caça e da pesca, bem como da coleta de frutos silvestres e de insetos. Agora, pcrém, os produtos da lavoura superavam em muito as demais fontes alimentares. Sem dúvida, os frutos doces da mata, um bom assado ou larvas de bezouros continuavam sendo apreciados como guloseimas, mas do ponto de vista quantitativo tiveram de ceder a dianteira ao milho, à mandioca e ao amendoim. Já não se dependia incondicionalmente dêsses recursos.

Também em outros setores o machado e a faca facilitaram o trabalho: na construção das casas, na confecção de diferentes objetos, na limpeza dos caminhos etc. Na minha última visita, em 1955, ocorreume a idéia de que talvez a aceleração do ritmo de trabalho provocada pelos utensílios de ferro tivesse criado um novo problema. Antigamente cada Tuparí devia trabalhar com afinco durante o ano todo se não quisesse passar fome com a sua família, ao passo que agora, graças às grandes provisões de mantimentos, os homens e rapazes não tinham quase o que fazer na estação das chuvas. Cheios de tédio, passavam semanas e 
meses na rêde, saindo apenas uma vez ou outra para alguma caçada. $\mathrm{E}$ nesses períodos os jovens revelavam, com freqüência, o desejo de voltarem para junto dos seringueiros de São Luís, onde sempre havia alguma atividade.

Ao passo que, portanto, a importância da lavoura aumentou muito do ponto de vista quantitativo, as espécies cultivadas, em sua grande maioria, permaneceram as mesmas. Plantas novas eram, para os Tuparí, a cana de açúcar, o arroz e a melancia; mas nenhuma delas alcançou grande importância para êsses índios. Novas variedades de feijão, de milho e de mamão parecem ter sido levadas ao Rio Branco pelos seringueiros; as espécies, porém, eram nativas.

Os métodos da lavoura por sua vez não sofreram alteração. Aliás, não diferiam muito dos que se empregam no território civilizado da Amazônia: feito o roçado e a queimada, planta-se a roça por um período de poucos anos sem uso de adubos e sem arar a terra, abandonando-a em seguida. A única inovação consiste em algumas enxadas de ferro, empregadas para capinar a roça antiga. Para o plantio e a colheita os Tuparí utilizam ainda os primitivos saracuás.

Pouco mudaram também os métodos de caça e pesca. Ainda em 1955 apenas um ou outro Tuparí possuía arma de fogo; a pólvora, o chumbo e as espoletas já haviam sido gastos. Tampouco se generalizou o uso do anzol: na maioria dos casos, os Tuparí continuam pescando, na estiagem, com auxílio de plantas venenosas.

Parece que muito antes da chegada dos seringueiros os Tuparí e seus vizinhos conheciam cães, galinhas e patos; receberam-nos provàvelmente através de outras tribos, que haviam estado outrora em contacto com missões ou com escravos fugidos. Os Tuparí pelo menos acreditam possuir desde sempre êsses animais. O cacique Waitó recebeu porcos domésticos de um administrador de São Luís, mas os animais morreram, provàvelmente por falta de experiência na maneira de tratá-los.

E' de certo interêsse também a reação dos Tuparí aos alimentos estranhos, isto é, a novas sensações gustativas e olfativas. Já em 1948 apreciavam várias coisas da alimentação dos seringueiros, especialmente - arroz, a farinha de mandioca, tão popular no Brasil setentrional, e, acima de tudo, o açúcar. A carne bovina era tida como prejudicial; para os médicos-feiticeiros constituía perfeito tabu, provàvelmente porque os Tuparí consideram o boi, portador de chifres, afim do veado, cuja carne o xamã também não pode comer. Quanto ao leite condensado, ainda em 1948 nenhuma mulher queria prová-lo, ao passo que a nova geração não revelava nenhuma relutância. Algumas mulheres aceitaram chá com açúcar, mas só após muita exortação. O sal vindo de São Luís já era artigo cobiçado, mas ainda havia, na época, várias mulheres que recusavam os alimentos temperados com o condimento de origem 
estranha. Em 1955, após repetidas e prolongadas permanências no seringal, os Tuparí se tinham acostumado ao consumo da carne de vaca, mas tampouco em São Luís os xamãs a comiam. Homens, mulheres e crianças aceitavam agora, de bom grado, leite condensado, café, chá e chocolate, de preferência com açúcar. E' curioso notar que, embora sabendo que o leite provinha da vaca, o próprio xâmane o bebia sem objeção. Ao contrário, Waitó afirmava até que as criancinhas que tomam leite condensado correm menos risco de morrer do que as outras. Ao sal de proveniência estranha todos se haviam acostumado, e alguns já rejeitavam o que tradicionalmente se extraía da cinza de palmeira.

Fato significativo para ilustrar o prazo requerido pela assimilação de novos processos é o de que os Tuparí, gostando imensamente de farinha de mandioca, não a fabricam, embora tenham em suas roças grandes quantidades de raízes dessa planta.

Muito difundida é a idéia de que também na América do Sul o álcool contribuiu, de maneira geral, para o desaparecimento das tribos indígenas. Não se pode, contudo, afirmar o mesmo para a região a que nos referimos, talvez porque a importação e a venda de bebidas alcoólicas teria sido demasiado prejudicial à própria emprêsa extratora da borracha. Por isso, até hoje as únicas bebibas embriagantes são as que se fermentam com milho, amendoim e diferentes raízes ou tubérculos. Só em época recentíssima os Tuparí conheceram em São Luís a aguardente de cana, muito apreciada pela população cabocla. De ordinário, porém, não se encontra à venda no barracão, de modo que não se pode falar de alcoolismo com relação aos Tuparí, nem aos índios do barracão.

Como as tribos vizinhas, também os Tuparí fumavam cigarros de tabaco. Podendo obter fumo importado do Pará ou da Bolívia, vários Tuparí hoje the dão a preferência. De modo gera1, considera-se agora mais elegante fumar cigarros feitos de papel importado do que os tradicionais cigarros de palha de milho. Parece também que, pelo convívio com os seringueiros, uns tantos índios se transformaram em fumantes inveterados.

Diversões, arte, música, adornos do corpo. - Uma das características mais notáveis da cultura Tuparí é a falta total de arte representativa, bem como de ornamentação elaborada. Neste setor os Tuparí também não receberam dos brancos estímulo de espécie alguma. Por outro lado, aprenderam uma série de canções com os seringueiros, outras com o grupo de viajantes que passou pela região com o jornalista $T$. Sekelj (1948), outras, enfim, com os missionários católicos. Era admirável a correção com que, decorridos sete anos, vários Tuparí ainda conseguiam repetir algumas dessas canções. As canções de origem estranha, entretanto, não fizeram desaparecer as tradicionais: cantam-nas ocasionalmente quando, sem motivo especial, algum cantor se lembra de fazê-lo. 
A maior influência dos brancos, no que respeita à música, deu-se por via indireta. Com a chegada dos forasteiros ao Rio Colorado e ao Rio Branco, os Tuparí passaram a visitar amiudadamente os Makuráp e, daí por diante, mantiveram com êles contactos cada vez mais íntimos em São Luís. Em escala crescente adotaram então a bem desenvolvida música instrumental e vocal dessa tribo, no que não fizeram mais do que seguir o exemplo dos Aruá, Wayoró, Jabutí e Arikapú, os quais abandonaram pràticamente a sua música tradicional, substituindo-a pela dos Makuráp.

Nas festas dos seringueiros de São Luís, os Tuparí tiveram ensejo, no decorrer dos últimos anos, não só de presenciar muitas vêzes as danças à européia, aos pares, mas também de participar delas ocasionalmente. Acham-nas muitíssimo divertidas, sem, no entanto, as imitarem na maloca. Dançam ainda segundo o velho padrão, em círculos concêntricos ou em filas, na maioria dos casos com separação dos sexos.

Como não houvesse entre os seringueiros o necessário desenvolvimento da vida social, os Tuparí não podiam aprender com êles nenhuma espécie de jogos. Os jogos de dados e de cartas, muito apreciados pelos brasileiros e bolivianos, em que os elementos azar e cálculo são de capital importância, não foram sequer adotados pelos índios do barracão por se afastarem demais do mundo mental dos indígenas.

O convívio com os brancos teve efeito negativo sôbre os enfeites do corpo. Parece que os homens passaram a usar em escala muito menor os seus adornos de plumas. Em 1948, por ocasião de uma festa, o cacique Waitó se queixava aflito: "Outrora os homens faziam sempre muitos enfeites de penas e nós dançávamos a noite inteira. Mas hoje os moços não querem mais". Já em 1948, e mais ainda em 1955, tornava-se evidente que os conceitos estéticos relativos à ornamentação do corpo se haviam transformado. Não havia mais nenhum homem Tuparí com orifícios bastante grandes nos lóbulos das orelhas para neles poder enfiar as hastes emplumadas. E a cobertura ideal da cabeça já não era o aro com penas, mas um chapéu de feltro ou um boné de pano.

$\mathrm{E}^{\prime}$ possível, entretanto, que mais outro fator tenha contribuído para diminuir a importância dos adornos de festa. Antigamente a tribo era numerosa, vivendo espalhada por um território relativamente extenso, ocupando uma porção de espaçosas malocas. A maioria dos irmãos de tribo só se encontrava por ocasião das grandes festas de bebida e de outras comemorações. Eram as oportunidades em que hóspedes e hospedeiros se esforçavam por aumentar o seu prestígio através do uso de belos enfeites. Por outro lado, em 1948 as últimas 40 famílias moravam tôdas muito perto umas das outras. Os membros da tribo se viam diàriamente, com o que os grandes adornos festivos parecem ter perdido a função. 
Quando em 1953 os Tuparí se transferiram definitivamente para São Luís, os homens começaram a abandonar também, cada vez mais, o enfeite do nariz, dos lábios e das orelhas; cortaram o cabelo à maneira dos seringueiros. As mulheres se mostraram bem mais conservadoras, mantendo, em geral, os adornos e o corte tradicional do cabelo.

Mas, fato curioso, ainda em 1955 as miçangas de vidro figuravam, ao lado de camisas, calças e vestidos de mulher, entre os presentes mais cobiçados pelos Tuparí. Homens e mulheres gostavam de usar debaixo ou por cima da camisa ou do vestido, cordéis grossos de sementes e miçangas, colocados obliquamente por sôbre o peito.

Indumentária. - Em 1948, homens e mulheres ainda costumavam andar nus. Poucos homens possuíam calça e camisa ou, pelo menos, uma destas peças, que vestiam quase só por ocasião de festas de bebida. Eram mais raras ainda as mulheres que tinham um vestido. Mas não havia dúvida alguma de que já naquele tempo a necessidade de se vestir era sentida de maneira geral. Os Tuparí não se cansavam de me pedir calças e camisas.

Em 1955 todos os homens possuíam calças e camisas, alguns até vários exemplares delas. Também a maioria das mulheres tinha pelo menos um vestido. Os Tuparí consideravam isso um grande progresso. Dispunham agora de uma proteção bastante eficiente contra os mosquitos, tão incômodos. Mas isto não era o principal. A função essencial da roupa parecia ser, para os Tuparí, a transformação do índio nu e selvagem no caboclo civilizado, participante do mundo dos brancos. Calça e camisa elevavam-lhes o status de maneira decisiva. Era essa a razão do orgulho que dominou o cacique Waitó quando um empregado do barracão o presenteou com um par de sapatos velhos: é que o proprietário e o administrador de São Luís também usavam sapatos de couro; e agora só lhe faltavam, ainda, para igualar-se a êles, um ou dois pares de meias e um chapéu de feltro novo. Julgava o seu status comparável ao dos "caciques dos seringueiros", e queria vestir-se de acôrdo. Considerar ridículas essas aspirações seria não compreender absolutamente a situação. A opinião corrente de que os missionários obrigam os aborígenes a se vestirem contra a sua vontade não se aplica pelo menos aos Tuparí.

Conhecimentos do mundo ambiente e idéias a seu respeito. Do que ficou exposto se depreende que, através do contacto com os brancos, os Tuparí tiveram bastante aumentados os seus conhecimentos e idéias acêrca do mundo ambiente. Até então tôdas as tribos corn que os Tuparí haviam entrado em comunicação tinham mais ou menos o mesmo aspecto físico e, além disso, uma cultura mais ou menos idêntica. Agora, porém, defrontavam-se com homens de pele branca ou preta, diferentes quanto ao cabelo e à forma do rosto, e com costu- 
mes - desde os cumprimentos por meio de apertos de mão até a economia baseada na divisão de trabalho - em muitos sentidos essencial. mente diversos dos que vigoravam na tribo. A isso acrescia o equipamento inteiramente estranho dos forasteiros: utensílios de ferro, armas de fogo, barco a vapor e a motor, indumentária etc. De onde teria vindo êsse novo elemento humano, constituiu grande mistério por longo tempo, até que aos poucos foram formando o conceito, a princípio obscuro, de "Guajará", correspondente a Guajará-Mirim, sede do município. Em "Guajará" morava o dono de São Luís, de lá vinham os seringueiros e, posteriormente, também os missionários, de lá os vapores e os barcos a motor traziam mantimentos e mercadorias, para lá transportavam o produto do trabalho anual. E quando, vez por outra, apareciam polícias em São Luís, êles vinham também de "Guajará". "Guajará" era para os índios a grande maloca dos forasteiros brancos e pretos e lá terminava o mundo.

Como eu não dispusesse de mapas geográficos, tentei em 1948 explicar aos índios, com auxílio de meu rádio portátil, que existem muitas outras "tribos" além de brasileiros e bolivianos. Sobretudo o inteligente cacique Waitó quis então saber onde é que se localizava cada um dêsses povos e qual o artigo principal de sua fabricação. Como xamã supremo, os novos conhecimentos o inquietavam bastante. Por que motivo não teria visto até então êsses povos estranhos quando a sua alma, em sonho ou em estado de transe, vagava pelo universo, chegando até os confins da terra, onde ela se encontra com a abóbada celeste? Também nos irmãos de tribo tão manifesta limitação do mago supremo provàvelmente devia suscitar certas dúvidas quanto às suas faculdades.

As representações do mundo além da área do Rio Branco continuavam para os Tuparí tanto mais obscuras, quanto até 1948 um único membro da tribo, de pouca idade, havia visitado Guajará-Mirim. Um grupo de homens desceu certa vez o Rio Branco até a sua embocadura no Guaporé. Isso, no entanto, não contribuiu muito para a ampliação dos conhecimentos. Os índios dependiam do que os seringueiros, os empregados e, mais tarde, os missionários procurassem explicar-1hes. $\mathrm{Na}$ missão, viram, após 1952, muitas fotografias e até fitas cinematográficas do mundo distante. Todavia, tudo isso antes os confundia do que esclarecia quanto ao que realmente se passava no mundo dos brancos. Uma coisa, entretanto, sabiam: que lá muito longe havia mais um mundo, que êles não compreendiam, mas com o qual, por certo, deveriam entrar em contacto.

Entre as coisas que os Tuparí não tinham entendido estava a divisão do tempo em horas, semanas e meses, bem como as medidas de comprimento, superfície e pêso. Em 1948, até mesmo Idum, que traba- 
lhara durante anos com os seringueiros, não entendera o sistema dos dias da semana e dos meses.

Depois de tudo isso, seria desnecessário dizer que os Tuparí não sabiam ler, nem escrever. Vários homens ainda moços cobriram, certa feita, com garatujas alguns pedaços de papel, querendo enviá-los ao barracão, a fim de, assim, fazerem a "encomenda" de mercadorias desejadas. Baseando-se no que haviam visto entre os seringueiros e comigo, julgavam que um pedaço de papel, em que se rabiscasse qualquer coisa em forma linear e com determinada intenção, bastasse para explicar ao administrador o que se desejava e fazer com que êle entregasse as mercadorias em aprêço.

Convém mencionar, por fim, que os Tuparí provàvelmente nunca chegaram tampouco a compreender o motivo pelo qual os forasteiros recclhiam tal quantidade de borracha e por que, afinal, haviam penetrado na região. A probabilidade de resolverem o problema era tanto mais remota quanto difîcilmente quaisquer artefatos de borracha terão chegado até o Rio Branco. Também as relações entre o administrador de São Luís e o dono da emprêsa, bem como a equivalência de valor entre borracha, mercadoria, trabalho, ou, enfim, a função do dinheiro escapavam inteiramente à compreensão dos índios.

Organização social. - No tocante à estrutura social e à vida comunitária, os seringueiros não apresentavam coisa alguma que pudesse incitar os Tuparí à imitação. Uma vez que o barracão, simples estação de troca de mercadoria e trabalho, constituía a única instituição visível dos forasteiros, na qual não havia nada que se prestasse para ser copiado na maloca, o contacto não teve influência alguma na organização social da tribo. A convicção dos Tuparí de viverem num sistema bom foi fortalecida pelo fato de que, após a introdução dos utensílios de ferro, nunca tiveram falta de mantimentos, o que não se pode afirmar de São Luís. Isto explica também a persistência da rotina geral nas atividades diuturnas e anuais, modificada apenas na medida em que a adoção dos novos instrumentos anulou a premência da procura de alimentos dia após dia.

Possìvelmente as relações com os brancos tenham influído de certo modo na posição do cacique. E' compreensível que os administradores de São Luís devendo tratar com uma horda de índios nus, falando língua estranha, preferissem entender-se com um representante dêles. Em virtude disso, o cacique, tornando-se uma espécie de capataz, veio a ocupar uma posição diferente da que the cabia na maloca. Os administradores e o dono do barracão, aliás, nunca tiveram consciência do descontentamento dos homens "simples" diante do tratamento preferencial dos caciques e até dos filhos e das filhas dêstes, dando-se-lhes remuneração 
muito maior, embora na realidade não tivessem trabalhado mais do que os outros ou até menos.

E' difícil saber em que medida o contacto com os brancos teria atenuado os conflitos internos da comunidade tribal. Quem ouve a narração das coisas passadas em épocas antigas, é quase induzido a admitir uma tendência nesse sentido. Os Tuparí dizem: "Antigamente não raro nos matávamos uns aos outros. Mas isto hoje em dia já não é bom; agora assim mesmo já somos tão poucos". Mais importante, porém, é talvez o grande respeito que os Tuparí tributam aos brancos de São Luís. Ninguém desejaria passar ali por assassino. Por isso é também improvável que os últimos Tuparí voltem um dia a ser antropófagos.

Ciclo de vida. - Tal como se deu com a organização social, pouco se modificaram os costumes referentes ao náscimento, à puberdade, ao casamento e à morte. Uma influência verificada na escolha dos nomes foi a de que em 1948 algumas crianças já haviam recebido nomes de civilizados. Mas não havia nisso pròpriamerte inovação, uma vez que também antigamente se adotavam, com freqüência, nomes usuais em outras tribos. Os novos nomes portuguêses que em São Luís foram dados nos últimos anos a muitos Tuparí adultos, principalmente homens, para maior comodidade, os próprios índios só empregavam em conversa com estranhos. Não obstante, parecia que vários dêles tinham orgulho de seu nome civilizado ou dos de seus filhos. E' que o nome português, da mesma forma como o uso de roupa, reduz o sentimento de inferioridade em face dos brancos.

No tocante às relações sexuais a permanência dos índios em São Luís não parece ter levado a mudanças muito importantes. Nitidamente se esboça uma transformação nos conceitos dos Tuparí relativos às partes do corpo que se devam considerar como pudendas. Ao passo que ainda em 1948 todos os homens ocultavam o órgão genital segundo a maneira tradicional, usando o característico estôjo peniano ${ }^{4}$, em 1955 êste se tornara pràticamente supérfluo em virtude da adoção das vestimentas dos brancos. De noite, entretanto, ainda o usavam com freqüência, e às vêzes também de dia, principalmente quando, por qualquer razão, calças e camisa eram incômodas, por exemplo, ao pintarem o corpo com suco de jenipapo (costume que não sofreu redução) ou durante o tratamento de alguma enfermidade pelo xamã. Era manifesto, porém, que, no banho e em ocasiões semelhantes, vários homens tinham relutância muito menor de expor o órgão genital. Ainda em 1955 a maioria das mulheres continuava a andar nua, embora quase tôdas possuíssem um vestido. De modo geral, ao que tudo indicava, não associavam ainda, de maneira específica, ao uso da roupa quaisquer sentimentos de pudor. 
Foi também, por certo, em conseqüência do contacto prolongado com São Luís que em 1955 alguns casais passaram a dormir ocasionalmente na mesma rêde, ao passo que outrora o homem e a mulher sempre dormiam separados, o que ainda hoje é a regra. Entretanto, não é possível saber se os referidos casais imitavam os seringueiros ou talvez os índios Jabutí. Ao que sei, êstes são a única tribo da região que conhecia o costume.

Mais importante do que essas mudanças parcicis era uma certa emancipação da mulher, que parecia ir se definindo aos poucos. Em 1948 a antiga ordem não tinha sofrido quaisquer abalos sensiveis. Em 1955, porém, várias mulheres jovens falavam abertamente de sua intenção de abandonarem o marido e de passarem a viver com um índio civilizado de São Luís ou até com um seringueiro de fora. Essa linha de conduta fôra preparada, sem dúvida, pelo fato de que nos anos anteriores algumas mulheres Tuparí se haviam unido, de forma permanente, com índios de outra tribo e, em dois casos, com um empregado do barracão, tendo tido também relações sexuais ocasionais com seringueiros.

As relações sexuais entre índias Tuparí e o pessoal de São Luís se haviam iniciado em 1950, quando chegou à máloca um mulato vindo do barracão, com o intuito de mandar abrir uma picada em linha reta até Paulo Saldanha, lugar situado no Rio Branco, a fim de melhor colocar os Tuparí ao alcance do barracão. Êsse mulato, que já anteriormente tirara da maloca várias índias Jabutí, exigia agora dos Tuparí uma mulher jovem. Recebeu uma viúva de pouca idade, que passou a maltratar de maneira sádica, levando-a depois consigo a São Luís. Lá passou-a para um índio Makuráp e voltou à maloca dos Tuparí, onde obteve outra jovem, que maltratou da mesma forma. E' notável que ninguém tenha reagido a isso. $O$ cacique zangou-se apenas quando o mulato, que se arrogava o título de "rei dos índios", exigiu afinal categòricamente para si cinco mulheres jovens, entre as quais a mais nova das espôsas do próprio cacique. Em parte a tolerância dos Tuparí se explica pelo fato de se encarar, em princípio, o tratamento da espôsa como assunto particular do marido. Ademais, já tinham interêsse, de há muito, de estabelecer relações de parentesco com os forasteiros do seringal, o que se lhes afigurava como elevação de sua posição social e como liame mais seguro com a fonte de utensílios de ferro e outras coisas. E, por fim, encaravam o mulato como representante da emprêsa, com o qual de maneira alguma desejavam entrar em conflito. (Sòmente mais tarde, em 1954, matou-o um índio Jabutí, quanảo, após a epidemia de sarampo, perseguia as poucas índias sobreviventes que haviam fugido para a maloca e onde quis apoderar-se, com violência, de uma índia casada). - Como já foi dito atrás, as mulheres Tuparí absolutamente não generalizavam essas experiências negativas para todos os seringueiros. 
Mas não sòmente as mulheres se mostravam interessadas por um parceiro vindo do mundo dos brancos. Já em 1948 um jovem Tuparí, manifestou o seu descontentamento com relação às mulheres Tuparí e me pediu que eu the arranjasse uma "mulher branca e grande". Semelhantes desejos externavam-nos também alguns rapazes em 1955. Todavia, com o status que os Tuparí ocupavam em São Luís, não lhes eram acessíveis, normalmente, as índias do barracão, nem as mulheres dos seringueiros. Ouvi um só caso em que uma mulher branca, que fôra prostituta, convidou um jovem Tuparí a dormir com ela, o que êle, no entanto, rejeitou, por mêdo, ao que dizia.

Religião e magia. - Um setor muito pouco atingido por influências estranhas era a religião dos Tuparí. Além de nomes como "Deus" e "diabo", os Tuparí pouco ouviam das representações religiosas dos seringueiros. Na década que se seguiu a 1930 um missionário teve, por ocasião de uma visita ao Rio Branco, o primeiro encontro com dois homens Tuparí. Em 1952, como já foi dito acima, os padres fundaram em São Luís uma estação missionária, onde um dêles ficou residindo. O plano era o de estabelecer em São Luís os índios de tôda a área e de, após a atração de moradores brancos, se constituir uma comunidade maior, com igreja, escola, hospital e instalações industriais. No mais, porém, os índios continuariam a trabalhar com á emprêsa seringalista.

A partir de então, os Tuparí, quando se encontravam em São Luís, assistiam à missa rezada pelo padre, aprendendo os cânticos religiosos e, em pequena escala, a recitação das orações comuns. Especialmente o bispo que ali exerceu a sua atividade primeiro era muito benquisto pelos índios. "Dava-nos calças e camisas e facas, e sabia bem curar os enfermos". Na medida em que posso emitir juízo, foi mínima a sua atividade catequética. Esta devia iniciar-se plenamente só depois de construídos os edifícios da missão. Após a epidemia de sarampo, de 1954, os padres desistiram definitivamente da missão, derrubando as construções que haviam feito. Como única recordação visível, ficaram aos Tuparí os "santos", medalhas de alumínio, que os homens, as mulheres e as crianças gostam de usar no pescoço como enfeite. De modo geral, os Tuparí guardavam boa memória dos padres, mas indubitàvelmente nunca chegaram a entender bem o que êstes afinal pretendiam. Por sua vez, os missionários sabiam muito bem que a cristianização dos índios seria um processo bastante moroso, em grande parte pelas dificuldades lingüísticas.

Não admira, pois, que o cacique e xamã Waitó, a despeito de seu evidente interêsse pelas coisas sobrenaturais, em conversa comigo, em 1955, só tenha mencionado uma única vez os ensinamentos dos padres em conversa comigo. Queria certificar-se se também eu era de opinião que após a morte as almas dos brancos iam para o céu, isto é, para o alto. Parecia acreditar que isso valia apenas para os brancos. Waitó 
julgava, certamente por um mal-entendido, que o bispo, e também o administrador do barracão, haviam visto do avião as malocas dos "pabid" (nome que os Tuparí dão às almas dos mortos). E um empregado confirmara aos Tuparí, com malícia ou com boa intenção, que êle próprio já tinha encontrado a Waledjád, um mago primeiro e herói civilizador que desempenha papel importante na mitologia e no culto. Waitó ficou, por isso, muito desapontado ao ouvir que eu não encontrara êsses entes em minhas longas viagens. - Sòmente após uma pergunta direta de minha parte, declarou mais tarde, de passagem: "Sim, lá em cima está Deus, o grande Pai, e Maria, a grande Mãe; foi o padre que o disse". Mas não revelou nenhum desejo de discutir o assunto.

Se é que para os Tuparí constituía problema a posição social dos padres, que naquelas partes do Brasil é muito elevada, em todo caso não a compreendiam. Ao passo que em outras áreas do território habitadas por índios o bispo da missão era conhecido como "Papai Grande", nunca ouvi essa designação entre os Tuparí. A serraria, o armazém, a farmácia, a luz elétrica, o projetor de diapositivos e o de fitas cinematográficas etc. sem dúvida impressionavam os índios. Apesar disso, Waitó disse uma vez ao dono do barracão: "O bispo não é nenhum Papai Grande, o Papai Grande é você". E deu o seguinte argumento: "Um cacique dos brancos não trabalha, e o padre trabalha sempre". Parecia acreditar que o bispo trabalhava na serraria a serviço do dono do barracão, que apenas dava as suas ordens, ao passo que o bispo trabalhava intensamente dia após dia, mais do que um diarista ou um seringueiro.

Mencionamos, por fim, os esforços mal sucedidos de Waitó para compreender o celibato. Eis o nosso diálogo: - Waitó: "Os padres de fato não têm mulher?" - Eu: "Não". - W.: "Êles pensam talvez que pegam doença pela vagina de mulher?" - Eu: "Não". - W.: "Então êles não têm órgão sexual?" - Eu: "Têm. - Waitó pensava que os padres fôssem uma tribo de homens diferentes, cujos filhos nascessem sem relações sexuais. Pergunta: "Então os padres não têm mesmo pais?"

As relações com o mundo exterior. - Ainda a geração anterior dos Tuparí orientara as suas relações com outras tribos decididamente para sueste, na direção dos Rios Mequens e Corumbiara. Sobretudo uma tribo provàvelmente estabelecida no Rio Mequens \& de identificação duvidosa, a que os Tuparí chamavam "Kuairú", mantinha com êles trato amigável, e é certo que os Tuparí, que haviam sido uma tribo de cultura relativamente pobre, aprenderam muito com êles. Por motivo de inimizades pessoais romperam-se êsses laços pouco antes da chegada dos brancos ao Rio Colorado e ao Rio Branco. Daí por diante os Tuparí se voltaram para a direção dos estabelecimentos dos seringueiros e, com isso, na das tribos vizinhas localizadas pelo caminho. Com os Arikapú, mais próximos, já haviam mantido anteriormente esporádicás relações de amizade. 
Agora tamibém passaram a ter trato com os Makuráp e Wayoró, entre os quais os Tuparí até essa época tinham, provàvelmente com razão, a fama de perigosos guerreiros e antropófagos. A ligação com os seringueiros fêz que, a partir de então, os Tuparí, tôda vez que quisessem trabalhar em Paulo Saldanha, e, mais tarde, em São Luís, tivessem de caminhar vários dias seguidos pelo território dos Jabutí, tribo desprezada que só através dos Makuráp se tornara um pouco menos arredia e culturalmente um pouco mais rica.

Verificou-se, pois, importante mudança de orientação. Não procuraram os Tuparí reavivar as suas relações com os "Kuairú". Preferiam o trato com us vizinhos, através dos quais pudessem obter utensílios de ferro. Eram êles principalmente, como se verificou, os Makuráp, com os quais a convivência era mais fácil do que com os Jabutí, de índole estranha e imprevisível. O fato de o cacique Waitó, quando moço, ter ido viver e trabalhar por algum tempo com os Makuráp revela bem a sua inteligência. Logrou fazer com um cacique e feiticeiro temido uma amizade tal que êste, além de o adotar como "irmão", the deu uma filha ainda criança para futura mulher. $\mathbf{E}^{\prime}$ verdade que esta voltou depois para junto de sua família, acabando por casar-se com um Mckuráp. Mas em conseqüência da relação de parentesco com a conceituada tribo, Waitó conseguiu nela garantir para si certo direito doméstico. O irmão da referida jovem, que continua sendo considerado como seu cunhado, tornouse mais tarde capataz em São Luís; em virtude disso, Waitó tinha uma relação legítima com o comércio dos brancos e, por conseguinte, com a fonte das cobiçadas mercadorias de "Guajará". Certos as viagens a São Luís, cada vez mais freqüentes, tinham também os seus aspectos negativos. Ficaram sendo regulares os contactos com as diferentes tribos. Não tardaram acusações recíprocas relativas a mágia negra. Sempre que numa das tribos adoecia ou falecia alguém, o que nesses anos era bem freqüente, responsabilizava-se o feiticeiro da tribo vizinha, o que era fonte perene de inimizades. Ainda em 1955 Waitó planejava um ataque a dois feiticeiros Jabutí, que moravam a alguma distância, aos quais responsabilizava pela morte de muitos Tuparí e até pela mortandade causada pela epidemia de sarampo do ano anterior e que por sua vez, havia pouco tempo, teriam morto a tiros a um médico-feiticeiro da própria tribo.

Em sentido diverso, entretanto, as relações com São Luís se revelaram como fator de segurança. Até por volta de 1900 os Tuparí tiveram de defender-se, em lutas sangrentas, contra vizinhos agressivos ao nordeste, provàvelmente uma tribo Tupí do Alto Rio Machado. Ainda em 1948 e em 1955 o perigo de um ataque da parte dêsses "Hamno" ou "Pauatö" se lhes afigurava como coisa muitíssimo real, sendo, aliás, bem possível que o mêdo dêsses inimigos figatiais já viesse, de longa data, fomentando o desejo de relações mais estreitas com os brancos. 


\section{$O$ comportamento individual e a reação emocional}

Para dar uma idéia bastante clara das múltiplas reações dos diferentes membros da tribo à nova situação, cumpriria mencionar centenas de observações particulares. De modo geral, pode-se dizer que os indivíduos jovens se mostraram mais fàcilmente influenciáveis pelos elementcs novos do que os mais idosos e, outrossim, que as mulheres foram mais conservadoras do que os homens. Mas também nisso havia exceções. Nos casos em que um novo elemento cultural trazido pelos branccs podia ser recebido sem considerável mudança na vida costumeira, além de vir ao encontro de uma necessidade de há muito sentida, a aceitação naturalmente era geral. Isto vale sobretudo para o uso de utensílics de ferro, contas de vidro para colares, e vestimentas. Grandes diferenças havia principalmente no tocante ao número de outros objetos que os diferentes membros da tribo consideravam desejáveis ou de obtenção possível, bem como na disposição de sacrificarem o seu tempo, cs seus esforços e sua independência para consegui-los. Os casos extremos representavam-nos, de um lado, os rapazes que viviam há vários anos no barracão, sem tencionarem tornar à maloca, e que, embora não esquecessem a cultura Tuparí, já não a praticavam; do outro, as mulheres velhas e também um cacique-xamã (falecido pouco antes de 1948) que cêrca de 15 anos depois do primeiro contacto ainda não tinha ido trabalhar com os brancos. E' verdade que passou a usar machado e faca, mas obtinha-os por intermédio de outrem, provàvelmente dos filhos, genros ou pacientes.

Isto nos leva a uma outra questão: Qual o juízo que os 'Tuparí faziam dos brancos e qual a sua atitude emocional em face dos forasteircs? - A primeira reação ao aparecimento dos brancos fôra de mêdo e terror. Em virtude das inauditas notícias inicialmente recebidas por intermédio das tribos vizinhas, os Tuparí chamaram os ádvenas de "tárüpa", i. é, "maus espíritos". A denominação "tarüpa" se conservou, mas as correspondentes associações de maus portadores de moléstia e morte se foram perdendo à medida em que a tribo entrou em contacto mais intenso com os seringueiros. Os Tuparí passaram a considerar a êstes como uma categoria especial de homens e até como companheiros, mas de maneira alguma como sêres individualmente superiores. De pessoas que ocasionalmente visitaram a maloca, seringueiros como etnólogos, exigiram até que os ajudassem nos trabalhos que no momento iam realizar, como o de fazer um roçado ou a construção de uma casa .

Por outro lado, uns tantos fenômenos do mundo dos brancos thes suscitavam sérios problemas que necessàriamente deviam redundar em sentimento de inferioridade. Assim, a ameaça imeginária, mas tida como real, dos "suldados" de Guajará-Mirim; o mêdo de um possível ataque dos aviões, aos quais atribuiam qualidades de feras, o que naturalmente 
incrementava de modo notável o prestígio de seus "domadores", os brancos; tôda a superioridade técnica dos ádvenas; a dependência, daí decorrente, com relação ao barracão, que era sentida com intensidade tanto maior quanto mais os Tuparí muitas vêzes não recebiam o que esperavam receber como remuneração de seus trabalhos, dependência essa tão grande que êles encarariam como grande desgraça se os brancos se retirassem inteiramente da região, obrigando-os a voltarem ao uso do machado de pedra. Trata-se, pois, de uma atitude emocional ambivalente em vários sentidos, que afinal, como adiante se verá, passou a se traduzir num sentimento de absoluta inferioridade.

Ao contrário de tôda expectativa, os Tuparí não parecem ter guardado nenhum ressentimento contra os brancos pelo fato de êstes lhes terem trazido as enfermidades de catastróficas conseqüências. E no entanto sabem muito bem que a grande mortandade se iniciou com a chegada dos "tarüpa". E' possível que a falta de práticas religiosas ou mágicas entre os seringueiros, que pudessem ser mal interpretadas, desde logo obstasse a suspeita de uma difusão intencional da moléstia; ademais, era patente que os homens do barracão desejavam, ao contrário, ter o maior número possível de trabalhadores. Os Tuparí buscaram, por isso, outras fontes causadoras do catarro, da malária e de moléstias novas: o motor (muitas vêzes irrompia uma epidemia de tosse depois de chegar do Rio Guaporé o barco a vapor com portadores de enfermidade catarral aguda), autores de magia negra, especialmente entre os Jabutí, e finalmente a atividade do mau espírito "tarüpa" e as almas dos feiticeiros falecidos. Não se faziam, porém, acusações contra determinados forasteiros, nem contra os brancos em geral.

\section{As causas da ruína}

Um observador que, sem conhecer o conjunto dos fatos, tivesse visitado em 1955 a derradeira maloca dos Tuparí, poderia ter a impressão de que, abstração feita do uso de utensílios de ferro e de indumentária européia, pouca modificação tinha havido na cultura tribal. A casa comunitária é construída em estilo tradicional. Nas vigas penduram-se cestas, cuias, rêdes de carregar, rêdes de dormir - tudo segundo o padrão de outrora. Pelo chão se veem banquetas, esteiras, potes e pratos de barro, recipientes de talos de fôlha de palmeira. As mulheres trabalham com o fuso como o fizeram desde sempre, fabricám louça de barro com longos cilindros de barro e sem o uso da roda de oleiro, e fazem cauim de milho com auxílio do pilão rotativo, invenção original dos índios dessa região. Os homens caçam predominantemente com arco e flecha. As antigas plantas de cultivo são, como dantes, plantadas e colhidas com auxílio do saraquá e da estaca de cavar. Com a naturalidade de sempre, os médicos-feiticeiros sentam-se juntos, uns soprando pós entorpecentes nas narinas dos outros, até estabelecerem contacto com espíritos 
celestes e almas dos mortos. Durante meses as meninas pacientemente aguardam os ritos pubertários atrás de um cubículo de esteiras, jejuando dias seguidos, permitindo, sem relutância, que se thes arranque tôda a cabeleira, e submetendo-se a complicadas cerimônias. Nem parece haver qualquer problema decorrente do choque das culturas. O que os Tuparí viram no mundo estranho parece coadunar-se perfeitamente com a manutenção das antigas tradições.

E' verdade que em 1955 os Tuparí haviam conservado ainda uma parte muito grande de seu patrimônio cultural. Mas um exame menos superficial tornou patente que, não obstante, a evolução dos últimos anos havia destruído as bases para a sobrevivência do resto da tribo com vida comunitária autônoma.

O fator decisivo foi, sem dúvida, a rápida áizimação da tribo pela ação das moléstias trazidas pelos seringueiros. O número de talvez 3000 Tuparí dá época anterior ao contacto ficou reduzido, no espaço de uma geração, a 66, dos quais ainda vieram a falecer alkuns pelo fim da minha visita de 1955. A tendência à extinção total é, pois, indubitável, tanto mais que os remanescentes, embora conheçam o perigo de novo contágio, não desistem do trato com os seringueiros. Abstração feita dos efeitos gerais de tão rápida redução numérica sôbre a vida comunitária, levou ela, em especial, a uma rápida destruição da consciência tribal. Como se dá com os portadores de tôda cultura não intelectualizada, os Tuparí se consideravam ántigamente o centro do mundo. Do ponto em que moravam se haviam dispersado as outras tribos na aurora dos tempos. Ainda em 1948 o cacique Waitó não achava outra explicação para a existência dos povos de que eu the falava senão admitir que, à maneira do que se dera com os Tuparí, algum de seus magos primevos os tivesse retirado do seio da terra, havendo êles então migrado para tão longe, que por fim se perdeu o contacto com êles. Em 1955, à vista do grupo reduzidíssimo de Tuparí ainda existentes, já não tinha absoluta certeza de sua teoria, principalmente depois de saber quão grande é o número de "brasileiros", "bolicianos" etc. espalhados pelo mundo. Compreendeu também que, mesmo nos bons tempos anteriores ao contacto, cs Tuparí e as tribos vizinhas haviam sido incomparàvelmente menos numerosas do que os povos estranhos.

A absoluta inferioridade técnica foi mais um fator a solapar decisivamente a auto-consciência dos índios. Também a êste respeito o cacique Waitó procurou uma explicação. Para êle, c herói civilizador Waledjád, que nos tempos míticos transmitira aos Tuparí o manejo das armas, o fogo e muitas plantas úteis, simplesmente se havia encaminhado depois aos brancos, tornando-se o cacique dêles e dando-lhes utensílios de ferro, armas de fogo e outras coisas mais. Tal explicação, porém, não eliminava $\mathrm{c}$ fato da superioridade dos forasteiros. Outros companheiros. 
de tribo talvez não pensassem tanto sôbre o assunito, preferindo usufruir a conseqüêrıcia prática, ao que o cacique, por seıı turno, não se furtava: procuravam manter-se em contacto com o mundo novo, a fim de parti. lharem das vantagens que oferecia.

Mas é preciso dizer que não se tratava de uma sujeição incondicional. Só mais ou menos meia dúzia de rapazes havia ficado em São Luís, transformando-se em índios de barracão. O cacique Waitó, e corn êle a maioria dos membros da tribo, se empenhava por encontrar outra solução. Queriam os índios trabalhar na extração da borracha, para obterem, na medida do possível, tôdas aquelas coisas que os índios do bar. racão e os seringueiros possuíam; mas não queriam abrir mão de sua independência, de sua casa comunitária e de suas próprias roças. Depois de 1954, quando a maioria dos Tuparí já se havia decidido pela mudança para São Luís, não tardaram descobrir que o ideal dessa coexistência não poderia realizar-se no barracão, nı convívio imediato com os seringueiros e os remanescentes de outras tribos. Então Waitó, com a anuência da administração, resolveu construir uma nova maloca a montante na localidade de Paulo Saldanha, que fôra abandonada. Dessa forma os Tuparí teriam, de um lado, a sua morada independente e, do outro, podiam ser aproveitados com facilidade na exploração da borracha.

Tal solução - independência, apesar da cunexão com um sistema econômico estranho - poderia talvez ser satisfatória por um certo perícdo de tempo. Depois, aos poucos os Tuparí restantes seriam dizimados ainda mais por novas ondas periódicas de enfermidades, até se mesclarem, por fim, com os índios do barracão e os seringueiros de fora. Eis que, porém, sobreveio o grande choque - a epidemia de sarampo de 1954 -, deixardo bem clara uma coisa: que os brancos não eram apenas incomparàvelmente mais numerosos e mais sabedores do que os Tuparí, mas que sòmente êles eram capazes de sobreviver às moléstias que sempre tornavam a irromper. "O nosso coração é muito fraco", queixavam-se os Tuparí. Os forasteiros nem mesmo eram atacados pelo catarro e pelo sarampo, ao passo que os índios morriam em grande número. O ânimo desfalecia ainda mais com o fato de os xamãs, em cujo poder de cura até então se havia acreditado, não terem poder algum contra as novas enfermidaces. Até os remédios dos brancos tinham pouco efeito, quando administrados aos índios. Assim, estava desfeito o sonho de uma coexistência na mesma área. Os Tuparí sobreviventes fugirain para a maloca que, havia pouco mais de meio aro, tinham abandonado com a intenção de nunca mais voltar. As 15 famílias, constituídas em sua maior parte de viúvas, viúvos e semi-órfãos, retomaram externamente a vida de antes. Mas o curso das coisas não deixa de seguir o sea rumo. Os jovens já tornavam a pensar na volta a São Luís para trabatharem como seringueiros. O filho do cacique confessou ao administra- 
cor: "Esperem até que meu pai morra, então virei aqui para sempre". O próprio Waitó tinha consciência de que os velnos tempos haviam acabado: "Quando eu morrer, não haverá mais maloca por aqui", dizia êle. Será, portanto, uma questão de poucos anos a fusão do resto dos Tuparí com os índios do barracão e com os seringueiros de fora, desaparecendo, assim, o último grupo da tribo que, embora ainda funcione exteriormente, já não tem coesão interna.

Cabe a pergunta: Poderia o desenvolvimento, nas circunstâncias observadas, ter se processado em outro sentido? Da comparação com o que se verifica em outras regiões do Brasil e das restantes partes da América do Sul tropical se depreende que as tribos do tamanho da dos Tuparí e mesmo tribos maiores têm tido, na maioria dos casos, destino semelhante em contacto $\mathrm{ccm}$ a civilização. Sem exagêro pode-se dizer que até hoje o único recurso infalível para a sobrevivência dessas tribos tem sido a exclusão violenta de quaisquer estranhos, quer sejam seringueiros, missionários ou pioneiros do Serviço de Proteção aos Índios. Há determinadas tibos, como, por exemplo, os Tenetehára do Brasil oriental, que, graças a circunstâncias favoráveis, resistirarn biològicamente apesar de longo trato com os vizinhos brasileiros, conservando ainda, em graiı notável, a organização social e a religião. Mas até observadores otimistas reconhecem que o progressivo desbravamento econômico do país levará ao extermínio as sociedades indígenas e as suas culturas. Do tamanho da tribo, de sua capacidade biológica de resistência, da modalidade do contacto e de umas tantas casualidades dependerá a extinção ćo grupo pelas novas doenças antes de perder a sua cultura tradicional ou o êxito de um número mais ou menos considerável de sobreviventes no sentido de se integiarem social e culturalmente na população do interior brasileiro.

\section{NOTAS}

(1) Observações gerais feitas na primeira viagem e informes sôbre o contacto dos Tuparí com a civilização já os apresentei, para um círculo de leitores mais amplo, num livro de viagem (Tupari, Brunsvique, 1952; tradução inglêsa: Tupari, Londres, 1956) e num trabalho intitulado "Los Indios Tupari y la Civilización" (Miscelanea Americanista, vol. 3; Madri, 1952). Os fenômenos em aprêço serão discutidos também, em outro enquadramento, num estudo monográfico ora em elaboração com o auxilio financeiro do Fundo Nacional Suiço.

(2) Veja-se E. H. Snethlage, Atiko y. Berlim, 1937.

(3) E. H. Snethlage, Atiko y, págs. 129-130-152. Segundo uma informação particular, teriam sido mais de 60 famílias. Pequena parte dos índios conseguiu evadir-se, alcançando a sua região natal depois de caminharem várias centenas de quilômetros pela mata virgem.

(4) Veja-se F. Caspar, Some Sex Beliefs and Practices of the Tupari Indians. Revista do Museu Paulista, vol. 7.․ São Paulo, 1953; págs. 207211 , pranchas I, II. 